This is an Accepted Manuscript of an article published by Taylor \& Francis in The International Journal of Human Rights on 20 May 2019, available online: http://www.tandfonline.com/10.1080/13642987.2019.1607211 


\title{
Human rights and development: The advancement of new campaign strategies
}

Hannah Miller, Department of Politics, Kingston University, London UK h.miller@kingston.ac.uk

\begin{abstract}
Contemporary scholarship has overwhelmingly focused on 'rights-based approaches' (RBAs) to development as being the principle way that development and human rights have merged in NGO practice. This article focuses on development-orientated campaign strategies, and in so doing challenges the ongoing RBA fixation by considering two praxis developments: 1) despite firm rejections of RBAs, alternative human rights strategies are being embedded in contemporary NGO practice, and; 2) over the past six years key changes in wider NGO campaigning contexts and environments have led to a further development in human rights approaches. Drawing on empirical findings from a ten-year in-depth research project on NGO practice, this article not only tracks developments in campaign practice, but also proposes two new models for consideration. These models - 'rights-framed' and 'rights-referenced', as practiced by influential NGOs - offer an innovative, strategic and instrumental embedding of a human rights discourse and practice.
\end{abstract}

Key words: rights-based; NGO; framing; poverty; activism; campaigning, human rights

\section{Introduction}

Despite the sustained dominance of 'rights-based approaches' (RBAs) to development (in both theory and practice), firm rejections of such approaches are increasingly emerging. In particular, many development-orientated NGOs - campaigning on areas that focus primarily on economic and social justice - are deeply concerned by the grave limitations that such approaches give rise to. Instead new innovations in rights practice are emerging across various NGOs, with the aim of overcoming many of the issues previously experienced and/or widely observed.

Drawing on empirical data from a ten-year research project, this article provides a comparative and qualitative analysis of human rights campaign practice and approaches. It takes a sociological approach to the study of rights and development. It especially questions why and how activists within development-orientated NGOs are able to (and, moreover, feel the need to) make statements 
to the effect of 'yes we [practice] rights, but we hate rights-based approaches.' It also charts deepened understandings of what the benefits and insufficiencies are of a human rights discourse and practice. In particular it analyses senior campaign staff perceptions of the impact of utilizing a human rights analysis as the sole framework for understanding.

The remainder of this article is divided into four main sections. First, the literature review examines how existing scholarship has approached human rights strategies in the context of development. It does this by providing an overview of common receptions of RBAs, alongside broader definitions. Then it considers later trends and limitations in research. The conceptual and methodological approach of the research project is then introduced in section two. In the third section the main findings of the project are offered. These are presented in two parts. The first offers an overview of "rights-framed approaches. Greater attention is then directed towards the second phase in the project. Given the fact that there has been a significant change in practice over the last six years, the article uses data from the second phase to classify a new human rights strategy (proposed here as 'rights-referenced' approaches). A critical overview is provided of the main differences between the three contrasting approaches ('rights-based', 'rights-framed' and 'rightsreferenced' approaches). Lastly, the implications of the findings are given.

\section{Background and context}

\section{Trends and limitations in contemporary scholarship}

For the last two decades the dominant way in which the available literatures have accounted for the merge of human rights with development-orientated practice has been through the materialization and advancement of rights-based approaches (hereafter, RBAs) to development. Over this period a wide variety of actors from the global North and South have incorporated RBAs (including United Nations and multilateral agencies, major donors, international NGOs and local grassroots NGOs). ${ }^{1}$ Due to the prominence and influence of such actors, numerous studies have provided a wealth of research concerning RBAs.

Earlier literatures were focused on what RBAs to development are. $^{2}$ Unsurprisingly RBAs were identified to be varying and vast in both theory and practice. Indeed one of the louder claims consistently voiced was that there was no one-size-fits-all RBA. ${ }^{3}$ This understanding emerged from many findings that suggested something to the effect of 'there is no single, coherent rights-based 
approach, but a range of tentative and highly varied commitments among development agencies, ${ }^{4}$ or 'rights-based approaches could come to mean all things to all people: a loose and ill defined idea, which everyone can adopt as they can interpret it to fit their own interests.' 5 The latter led to the identification of the plurality of RBAs to development, and accordingly the ongoing examination of differing RBAs (both across and within development actors). ${ }^{6}$ The consequent staging of the plurality of RBAs to development has led to the prevailing message; that RBAs cover most (or, more ominously, all) human rights approaches across mainstream development practice. As I have previously argued, this rather mistakenly presents RBAs as a 'broad umbrella concept', which has been built on a 'one-approach-fits-all message" 7

In order to be able to challenge the underlying broad umbrella concept of RBAs - and with the aim of establishing a foundation for analysis - it is important to briefly turn to the definition of RBAs to development. As noted, there is no single definition of RBAs to development, however key dimensions have been identified. Very broadly, RBAs to development represent a shift away from voluntarism, 'need-based' and 'service-driven approaches'. ${ }^{8}$ At the most basic level, RBAs are grounded in human rights, and so typically start from or draw upon legal human rights standards (as codified in international and regional treaties, national law, or through the work of human rights bodies and courts). ${ }^{9}$ RBAs commonly place emphasis on universality, indivisibility and interdependence of all rights. ${ }^{10}$ Such a rights-based starting point impacts the way in which development work is carried out, and what the overall goal should be, or - as the Office of the High Commissioner for Human Rights (OHCHR) identified - the process and the outcome. ${ }^{11}$ That is, a normative grounding in human rights usually explicates how development-orientated work should be done (process), whilst the realization of a full range of rights is identified as fundamental to achieving the end goals of development (outcome). Further to this basing (of process and outcomes) on human rights concepts and standards, key RBA to development dimensions commonly include the prioritization of: 'non-discrimination'; popular 'participation'; 'empowerment'; 'accountability'; the rule of law and; for some, 'good governance'. ${ }^{2}$

Many RBAs to development have been differentiated based on their key emphases and interpretation, including for instance: an empowerment emphasis (pulling firmly on the mobilising and inspirational force of human rights practice); a legalistic emphasis (strongly routed in the full scope of legal standards and enforcement mechanisms); a grassroots emphasis (powerfully drawing on bottom up interpretations of rights practices); and a citizen rights emphasis (visibly distancing 
the approach from the international human rights system). ${ }^{13}$ Several RBAs to development also incorporate a blend of some of the above.

After more than a decade of RBA to development practice, academic research turned to focus more on the advancements of best practice (inclusive of 'added value', 'potentials' and 'successes') as well as the perceived 'pitfalls' and 'failures' of RBAs to development. ${ }^{14}$ Added to this were some important contributions that sought to address more challenging aspects - for instance, concerning the extent of 'real' organisational change following the formal incorporation of RBAs. ${ }^{15}$ There have also been a number of studies that have sought to analyse the wider power structures that continue to negatively impact the extent to which rights-holders are able to truly secure rights-based development. ${ }^{16}$ Of late, Nelson and Dorsey ${ }^{17}$ have also questioned the extent to which RBAs have led to 'transformative changes' and overcome the various limitations that previously impacted effective implementation. Without doubt such studies are critical to this wider field of study, with their contributions leading to a rich RBA analysis.

An issue remains however - and this is core to the argument presented here - that further research is needed concerning human rights and development models that sit firmly outside and beyond RBAs. ${ }^{18}$ This issue stems from the ongoing and inherent affirmation of the broad umbrella concept (built on the 'one-approach-fits-all message'). Essentially RBAs to development are commonly seen to cover the broad spectrum of human rights practice (as illustrated by Figure 1 below). That is, there is limited research that has identified any real distinction between rights strategies (be them strategies that incorporate a 'thick' use of rights, a 'thin' use, or somewhere in between). Indeed, to illustrate further the extent to which research has become fixated on this concept, one only needs to turn to Kindornay, Ron and Carpenter's study, published in Human Rights Quarterly, which speaks of a 'rights-based development sector' and a 'rights-based cascade. ${ }^{19}$

Figure 1. RBAs spanning the human rights spectrum, as overestimated by various literatures

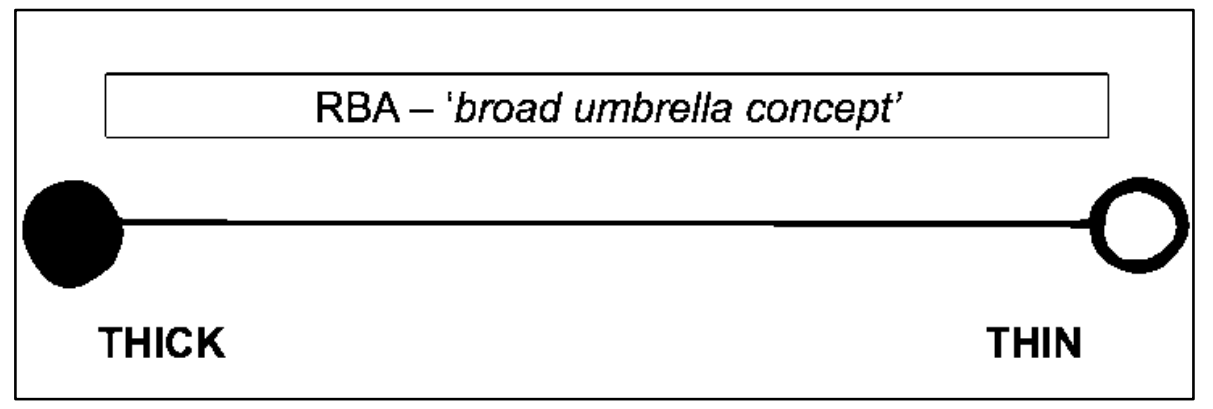


Instead the data analysed below provide further evidence of growing trends where formal RBAs are being firmly rejected by development-orientated actors, whilst a practice of rights is still being clearly advanced. With the latter in mind, this research project sought to question what the alternative human rights models might look like (as illustrated by Figure 2).

Figure 2. RBAs and emerging approaches located across the human rights spectrum

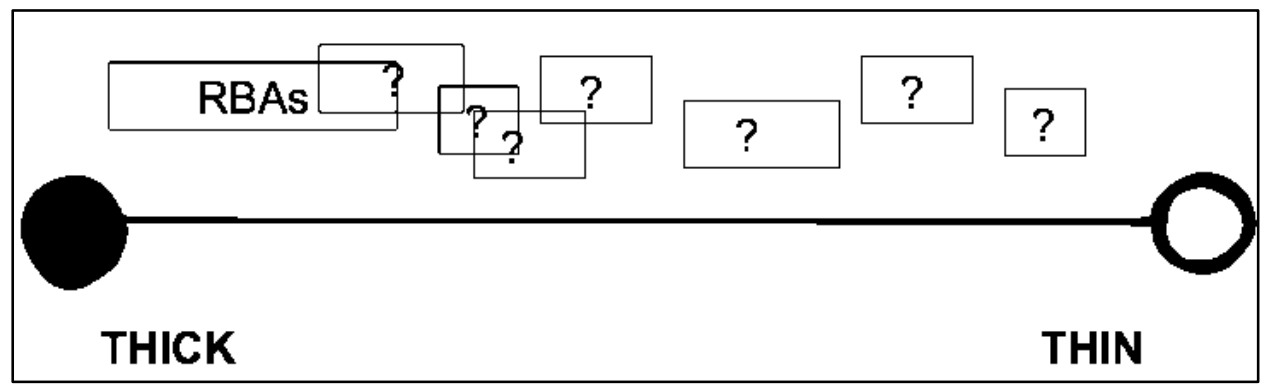

At this point it is imperative to acknowledge that whilst most academic research has been focused on the various RBA to development theories, policies and practices, a few have investigated areas related to this present contribution. The similarity lies in the focus of human rights approaches outside of RBAs, but from the viewpoint of bilateral and multilateral donor and aid agencies (rather than NGOs, as in the case here). Uvin ${ }^{20}$ is notable for this - through his 'rhetorical incorporation', 'political conditionality', 'positive support' and 'rights-based approaches' categories. For him, there is an assumption (or, at least, a desire) of a linear movement towards RBAs. Likewise, Piron and $\mathrm{O}^{\prime} \mathrm{Neil}^{21}$ and WB/OECD-Compendium ${ }^{22}$ also provide some insight into different donor approaches - through their 'implicit human rights work', 'human rights projects', 'human rights Dialogue', 'human rights mainstreaming' and 'human rights-based approaches' categories. ${ }^{23}$ Such categories identify where rights have been fully integrated (through RBAs) and also where wider approaches lean towards a thinner incorporation.

\section{The research project}

The project drew on the emerging (yet significant) contributions of the sociology of rights, and also political sociology and social movement theory more broadly. Specifically, it utilised a social constructionist perspective of the practice of human rights. This recognises the significance of social interaction in the production, struggle and advancements of rights (as a concept and as a practice). It also acknowledges that the discourses and practices of rights (as they emerge from 
social interaction) should be scrutinized, rather than necessarily being accredited as beneficial to the very individuals and communities they seek to defend. ${ }^{24}$ As part of this, the project focused on the 'social life of rights', and specifically, uses of 'rights talk. ${ }^{25}$ Wilson identifies this to relate to 'how people speak about [human rights] norms, or aspire to expand or interpret them in new ways. ${ }^{26}$ With this in mind, a key concern of the project has been to establish:

- how development campaigners understand and interpret various claims articulated in the language of human rights

- to what extent, and in what ways, they accept or reject human rights frameworks in campaign practice

- and, what they hope to gain as a result of this. ${ }^{27}$

In undertaking an assessment of human rights approaches, the project specifically focused on the campaign strategies of nine UK-based development-orientated NGOs (namely: ActionAid UK, Oxfam GB, Save the Children UK, War on Want, Global Justice Now ${ }^{28}$, Jubilee Debt Campaign, Christian Aid, CAFOD and Tearfund ${ }^{29}$ ). Between 2007 and 2018 over eighty in-depth interviews, eight focus groups and one five-month ethnographic study were conducted. Research participants included Chief Executives, Campaign Directors, Senior Campaigners, Senior Policy Advisors and lead activists. Alongside this, in-depth documentary analysis was conducted (of campaign material and NGO strategy papers). The data presented below cover the two phases of the project. The first section offers a summary of findings from phase one (2007-2011). The second, more detailed, section provides a more in-depth analysis of phase two (2012-18).

\section{Findings and proposals}

\section{The first phase (2007-2011): identifying rights-framed approaches}

One of the central findings of the research project has been that basing an approach on human rights is not the only way to incorporate a practice of rights. That is, by contrast to rights-based approaches, the project initially identified:

- 'Rights-framed approaches' (RFAs): these incorporate a human rights discourse and practice instrumentally at the operational level, through the strategic use of rights framing.

The classification and proposal of this model emerged directly from the earlier phase of the project, grounded in the experiences of those working in the field. The identification of the approach was 
developed together with the research participants, enabling them to openly self-identify with the new model. That is, not only did the proposal of RFAs provide a taxonomy of existing practice, but many participants also spoke of how it helped to develop wider strategies (through allowing them to articulate a human rights approach outside of RBAs).

RFAs - as fully embedded in contemporary NGO campaign practice - are summarised as:

... a tool, used to serve an NGO's policy. That is, they do not start from, and are not defined by, a normative understanding of human rights (by comparison to RBAs), but instead are driven by the ideological underpinnings of individual NGOs. From this basis conceptualisations of poverty, end goals of development and strategic priorities are not defined by concepts of human rights or human rights standards, but are instead driven by the ideology of the NGO. However, while a normative understanding of rights may not define their basis for analysis, a human rights frame is used. Expressly, RFAs incorporate the language of rights as a way to repackage the ideological underpinnings of an NGO in order to benefit from a number of strategic frame dimensions. Through this, NGOs are able to utilise the power of the idea of universal rights to motivate others, but only when it is considered to be strategically advantageous to specific campaign contexts... rights talk is identified to be somewhat varied... Various campaign methodologies can be invoked through RFAs, however those practising 'solidarity campaign' strategies have the most to gain from such approaches, and are thus more likely to apply it. ${ }^{30}$

Examples of where human rights framing came to the fore, could for instance be seen in War on Want's Palestine campaign (in its calls to end the occupation of Palestine; its exposure of companies complicit in Israel's "crimes", and; in its solidarity with the global movement calling for boycotts, divestments and sanctions); Tearfund's campaigning around water and sanitation (in its calls for the realization of 'water as a human right'), and likewise; the World Development Movement's water campaign (where it mobilized activists, calling for the UK Foreign Office to support an enforceable 'right to water' at the UN level, and for the UK Department for International Development to change its policy towards promoting water as an essential right). ${ }^{31}$

\section{The second phase (2012-17): identifying rights-referenced approaches}

Early on in the second phase of the research project it become abundantly clear that there had been a shift in approaches. Five of the $\mathrm{NGOs}^{32}$ covered in the study were gently repositioning themselves within the wider sector vis-à-vis their use of a human rights discourse and practice. Consistent to the earlier findings, again they demonstrated that basing an approach on human rights was not the only way to advance a human rights strategy. Instead data demonstrated that they had also moved from strategically incorporating rights-framed approaches towards an approach that was more particular about its use of rights talk. Participants began to readily self-identify with what are proposed here as rights-referenced approaches (hereafter, RRAs). 
Before providing an analysis of some of the detail of RRAs an overview would be helpful. At the most basic level, RRAs exhibit a thinner use of rights talk, by contrast to rights-based and rightsframed approaches. The latter is a consequence of the fact that RRAs invoke a more nuanced use of rights talk through the very deliberate embedding of rights referencing (by contrast to basing or framing).

RRAs are built on the identification that a human rights discourse or practice does not, in any way, define the conceptual level of the NGO. That is, the NGO still maintains a core and critically separate ideological base, which is not dependant on any ideas of rights. RRAs are somewhat similar to rights-framed approaches, in that they act as a tool, incorporated as a means to serve the wider approach of the NGO. However wider beliefs and ideas are repackaged through alternate frames. Consequently, RRAs decentralise both the value and power of rights talk through the very explicit choice to refrain from rights basing or framing. Rights talk is however used very instrumentally (and very precisely and powerfully) at the operational level. As the data below will demonstrate, this is especially evident through the incorporation of rights talk when communicating key campaign phases and actions.

For the purpose of developing this overview Table 1 (below) provides a further summary of RRAs, by contrast to rights-based and rights-framed approaches. Vertically the table reveals the extent to which human rights (inclusive of concepts, discourses and practice) are centralised within a single approach. The upper section of the table identifies key distinguishing features at the 'conceptual level ${ }^{33}$, and accordingly unpacks how far ideas of rights are used as a basis to orientate (and justify) an NGO's approach. The lower part of the table turns to the 'operational level' of an NGO and establishes a typical use of rights discourse and practice directly related to campaign strategies. By looking horizontally across the table the overarching and distinguishing features of the different approaches can be observed. 


\begin{tabular}{|c|c|c|}
\hline Rights-Based Approaches & Rights-Framed Approaches & Rights-Referenced Approaches \\
\hline The official approach & $\begin{array}{l}\text { Used as a tool to serve the official } \\
\text { approach }\end{array}$ & $\begin{array}{l}\text { Used as a tool to serve the official } \\
\text { approach }\end{array}$ \\
\hline Drives NGO policy & Is driven by NGO policy & Is driven by $\mathrm{NGO}$ policy \\
\hline $\begin{array}{l}\text { Orientation is defined by } \\
\text { universal ideas of human } \\
\text { rights. Distinctions can be } \\
\text { identified between an } \\
\text { 'empowerment' and } \\
\text { 'legalistic' emphasis } \\
\text { 34 }\end{array}$ & $\begin{array}{l}\text { Starts from ideological base of the NGO } \\
\text { (for e.g. socialist ideology). Then on } \\
\text { strategic occasions will repackage } \\
\text { beliefs and ideas through a human rights } \\
\text { frame }\end{array}$ & $\begin{array}{l}\text { Starts from ideological base of the NGO } \\
\text { (for e.g. socialist ideology/ faith-based } \\
\text { teaching). Will repackage beliefs \& ideas } \\
\text { through an alternate frame (for e.g. social } \\
\text { justice/ solidarity). Then on strategic } \\
\text { occasions will utilise rights referencing }\end{array}$ \\
\hline $\begin{array}{l}\text { Conceptualizes poverty } \\
\text { based on absence of human } \\
\text { rights }\end{array}$ & $\begin{array}{l}\text { Conceptualizes poverty based on } \\
\text { ideological base (for e.g. inequality) }\end{array}$ & $\begin{array}{l}\text { Conceptualizes poverty based on } \\
\text { ideological base (for e.g. inequality) }\end{array}$ \\
\hline $\begin{array}{l}\text { Justifies approach based on } \\
\text { concept of universal human } \\
\text { rights }\end{array}$ & $\begin{array}{l}\text { Concept of universal human rights is } \\
\text { used as the basis for legitimacy in } \\
\text { precise contexts (only when considered } \\
\text { to be strategically advantageous). } \\
\text { Otherwise justification comes from } \\
\text { alternate base (for e.g. 'solidarity') }\end{array}$ & $\begin{array}{l}\text { Justification comes from alternate base } \\
\text { (for e.g. 'solidarity') however for some, } \\
\text { very strategic references may be made to } \\
\text { rights talk (primarily to demobilize } \\
\text { antagonists) }\end{array}$ \\
\hline $\begin{array}{l}\text { Mobilizes others by pulling } \\
\text { on the power of the idea of } \\
\text { universal human rights }\end{array}$ & $\begin{array}{l}\text { Will strategically utilise the power of the } \\
\text { idea of universal human rights to } \\
\text { mobilize others }\end{array}$ & $\begin{array}{l}\text { Rarely uses rights talk to mobilize others, } \\
\text { instead uses alternate frames (for e.g. } \\
\text { global justice, 'Jubilee' concept, faith- } \\
\text { based teaching) }\end{array}$ \\
\hline $\begin{array}{l}\text { Embeds a human rights } \\
\text { analysis in argumentation. } \\
\text { Frequently cites specific } \\
\text { human rights language, } \\
\text { covenants or agreements }\end{array}$ & $\begin{array}{l}\text { On occasions, \& only when beneficial, } \\
\text { will appeal to ideas of rights and/or cite } \\
\text { specific human rights language, } \\
\text { covenants or agreements in } \\
\text { argumentation \& explanation }\end{array}$ & $\begin{array}{l}\text { References a more organic discourse of } \\
\text { rights (not normatively defined). Rights } \\
\text { referencing is used strategically during } \\
\text { argumentation \& explanation }\end{array}$ \\
\hline$\left[{ }^{*}\right.$ No data available $\left.{ }^{*}\right]$ & $\begin{array}{l}\text { Repackages beliefs through a human } \\
\text { rights frame to demobilise antagonists }\end{array}$ & $\begin{array}{l}\text { Will strategically make reference to ideas } \\
\text { rights to demobilise antagonists }\end{array}$ \\
\hline $\begin{array}{l}\text { Typically involved in the } \\
\text { formation of new } \\
\text { international standards }\end{array}$ & $\begin{array}{l}\text { Will utilise critical moments to critique } \\
\text { or push the boundaries of existing rights } \\
\text { standards }\end{array}$ & $\begin{array}{l}\text { Will utilise critical moments to critique } \\
\text { or push the boundaries of existing rights } \\
\text { standards }\end{array}$ \\
\hline $\begin{array}{l}\text { Multiple backstage voices of } \\
\text { rights talk }\end{array}$ & Multiple backstage voices of rights talk & Multiple backstage voices of rights talk \\
\hline
\end{tabular}

Table 1: distinguishing between rights-based, rights-framed and rights-referenced approaches

The contrast across the approaches not only reveals the uniqueness of RRAs, but it also illustrates further the extent to which new approaches are developing outside of rights-based approaches. It is important to note that although some differences may appear incremental on first sight, they do indeed lead to very different campaign approaches and strategies (as will be demonstrated below).

The following sections present a core selection of findings that are symptomatic of the wider trends observed across RRAs. These sections help to provide further context to the detail provided in Table 1. The data relate to how, why and when a human rights discourse and practice has been incorporated in campaign practice (and, of equal importance, when it has not been). The sections are organised first by key dimensions that relate to the conceptual level of RRAs ('orientation', and 'justification') and then, by those that concern the operational level of RRAs ('mobilisation', 
'explanation and argumentation', ‘de-mobilisation', 'expansion and transformation'). ${ }^{34}$ By focusing on these key dimensions clear distinctions can be made as to where RRAs differ in practice from rights-based and rights-framed approaches.

\section{(Not) Orientation}

A core aim of the research project was to investigate the extent to which campaigners accepted or rejected human rights frameworks, and the various ways in which this was materialised. This line of questioning led to the most fervent and impassioned reason for rejecting RBAs. This finding was consistent throughout the entire project (even in the first phase, when RFAs were identified). Specifically, the tension lay with the idea of orientation. Essentially every participant - across all five NGOs - was concerned with where an approach based on human rights frameworks leads an NGO and its campaign practice. That is, if an NGO relies solely on the full realisation of a range of (legal) human rights to provide the vision for the end goals of development, then the trepidation is that it will lead the NGO towards a grave set of outcomes. From this premise, RBAs that pulled on a discourse and practice of rights at the conceptual level were identified to be: too liberal ${ }^{35}$ too legal or technocratic; ${ }^{36}$ too focused on the individual; ${ }^{37}$ too constraining and restrictive ${ }^{38}$ and for some; certainly not political enough. ${ }^{39}$

Indeed, many spoke of the de-politicised nature of RBAs. This is a significant finding, as it stands in stark contrast to existing RBA scholarship, which has largely asserted that grounding development approaches in human rights through RBAs offers the chance to re-politicise development. ${ }^{40}$ By contrast, participants practicing RRAs identified that a human rights analysis per se, simply 'did not go far enough'. ${ }^{41}$ For example, War on Want's Chief Executive spoke of human rights as enabling 'a two rather than three-dimensional analysis of power'. ${ }^{42}$ A key basis for this understanding arose from decades of campaigning with the Palestinian peoples. War on Want had frequently observed RBA NGOs reporting human rights violations from both sides of the Israel-Palestinian conflict. While this in itself did not necessarily appear to present an issue for War on Want, the absence of a political analysis did. The issue related to the fact that a normative interpretation of the Universal Declaration of Human Rights and other human rights standards orientated the shape of many RBA campaigns (leading RBA NGOs to defend the rights of Palestinian and Israeli Peoples equally). However, through an RRA, War on Want purposefully stood in solidarity with the Palestinian Peoples and their plight alone (out of their belief of defending the 'just cause' of the wider solidarity movements across Palestine). ${ }^{43}$ 
More broadly - where participants strongly rejected the idea that a human rights framework and analysis should orientate the ideological or conceptual basis of an NGO - faith-based teachings, a social justice analysis, (leftist) political ideologies and/or socialism were seen by contrast to be more appropriate and powerful. Such orientations also reflected the critical sets of beliefs and ideas that characterised the particular culture of each respective NGO. The rejection of embedding a human rights framework at this level, squarely positioned each NGO's human rights approach outside of RBAs, whilst also providing the first building block of an RRA.

\section{(Not) Justification}

Further to the research project's aim of establishing the extent to which participants accepted or rejected a human rights framework, the wider tension of 'justification' emerged as a key concern. That is, whether participants from within each NGO would draw on the detail of different frameworks (international, regional, national, local) to provide the rationale for developing a particular campaign focus or strategy. By contrast to RBAs - that start from human rights frameworks, typically invoking ideas of international consensus and agreement as a basis to justify campaign approaches and calls ${ }^{44}$ - RRAs firmly rejected the idea of appealing to rights frameworks. This became an important finding that helped to further distance RRAs from RBAs.

Neither human rights frameworks nor discourses were utilised as a basis to substantiate or justify campaign strategies or positions. Indeed, it was deemed neither necessary nor desirable. Many participants spoke of the "western bias" of rights as being highly problematic for western-based NGOs. ${ }^{45}$ For instance, participants made comments like, “I can't understand why a group would want to try and advance western ideals in a context that does not want to align itself with the West". 46

Some also pointed to instances where human rights violations had been used to justify international military intervention in conflict zones, such as Libya. ${ }^{47}$

Interestingly, there was not only a move amongst the NGOs represented across the project to reject the invoking of human rights frameworks at this level, but there was a further guiding principle behind such a choice. Essentially all participants spoke of the need to ground their overall approach in something that was built from a far more tangible and solid foundation (rather than what most considered to be highly contentious political and/or legal ones). Justifications came from alternate 
bases. An important and reoccurring finding was that the principle and practice of 'solidarity' was absolutely key. ${ }^{48}$ It became very apparent that participants were extremely comfortable in couching the rationalisation of an overall approach in something that was in line (and thus, in 'solidarity') with core foundations, analysis and/or worldviews of key groups fighting the root causes of their struggles. For example, participants made comments to the effect of, "we stand in solidarity with X peoples, and for that reason we can justify our calls." This ultimate rejection of incorporating a human rights framework as a base to substantiate overall approaches stands as a further RRA distinction.

\section{(Rarely) Mobilisation}

Critical to any campaign practice, is the need to mobilise others to take action and support the cause. ${ }^{49}$ This concern was certainly something that became a focus during many of the interviews, and what inevitably led to a wider reason for participants to reject RBAs. It also provided critical insight into one of the broader concerns of the project, which related to how campaigners understood and interpreted various claims articulated in the language of rights.

Data enabled a spotlight to shine on the extent to which participants spoke of the need to engage key UK-based audiences and to motivate them to actively bring forward and/or fight for change. At this most fundamental level, a discourse and practice of rights was not always considered to be inspiring. For many, rights were not seen to motivate nor enthuse people to take action.

This set of findings was certainly particular to this phase of the project, and in so doing allowed for a point of departure from RFAs. In the earlier phase three of the $\mathrm{NGOs}^{50}$ had very consciously and deliberately centralised rights talk in their campaign activities through the process of framing. Then, human rights frames were used as a critical way to repackage ideas for the purpose of motivating and mobilising collective action. For instance, various campaign messages had pulled on the power of the idea of universal rights to motivate others. Key campaigns had also cited specific human rights language, covenants or agreements. ${ }^{51}$

By contrast, contemporary practice had somewhat shifted. That is, rights talk was being used as part of a wider narrative, and not typically for the purpose of mobilising. One reason for this change was based on some of the more technocratic approaches observed across the sector. ${ }^{52} \mathrm{~A}$ further (more overwhelming) reason was related to the strength and salience of alternate frames 
(global justice/ social justice/ 'Jubilee'/solidarity/ faith-based). Such frames were seen to be far more inspiring. Various reasons were offered as to why the traction of rights framing had loosened during this short period whilst others had strengthened, inclusive of: changes in UK governments (and the successive 2010 and 2015 administrations' calls to replace the Human Rights Act with a British bill of rights); parliamentary, press and social media coverage of the UK's 'Brexit' process (and broader calls to leave the wider European human rights system); the aftermath of the 2008 financial crash (and deeper understandings of the root causes of the problems in the economic sphere); the impact of the Arab Spring (and the power of social solidarity and resistance), and; the influence of the Occupy Movement (and the deepening of a political and 'power' analysis, including the framing of the ' $99 \%$ ').

The issue of inspiration was critical. For instance, one senior campaigner noted,

When you talk about "justice", "equality", "solidarity" there is a sense of a fight and a movement that people are inspired to be part of. When you talk about rights, there is more a sense of big NGOs coming in, with big philanthropic endeavors. ${ }^{53}$

The interesting point about the statement above (like so many collected during the second phase of the project) is the reference to a 'movement' and, critically, to a 'fight'. Time and again participants from the more (leftist) political NGOs explained how rights talk simply did not lead to a similar level of energy or fervency. The following statement, made by War on Want's Chief Executive provides further insight,

If we are speaking to a group of ardent lefties, we would very very rarely use the language of human rights. Although... if we were to talk about workers rights, they would be totally happy.... It's just that it no longer gets anyone out of bed... there's a lack of inspiration! That's perhaps the biggest shortcoming... There is a lack of inspiration in the framing of human rights. It's not a clarion call in the same way that justice is a call! ${ }^{54}$

The notion of 'calling people out to take action' was not limited to the (leftist) political NGOs and was instead central to the faith-based NGOs covered in the project too. For those participants faithbased teaching and 'social justice' frames provided the motivational element needed to press forward a successful campaign. However, by contrast to being motivated to 'fight', inspiration came through 'justice', 'love', 'dialogue' and 'common good.' 55

These findings are indicative of wider trends across the data set. They reveal the absolute need for powerful frames to be invoked during key phases of mobilisation. The significance of framing is of course something that has been well documented across academic research ${ }^{56}$, with human rights framing being identified as a key attribute of RBA and RFA theory and practice. ${ }^{57}$ It is thus hugely 
significant that the most recent data set paints a different picture. It offers a new picture where NGOs are shifting away from using rights framing in campaign strategies whilst still incorporating a human rights practice.

\section{Explanation and Argumentation}

With the broader aim of examining how campaigners comprehend and interpret various rights claims, data also provided new insight into key strategic choices. A critical finding across phase two of the project was that rights talk was used as a central part of the explanation and argumentation of key campaigns. This was done through rights referencing. Some NGOs opted to embed rights talk slightly more frequently (War on Want, Jubilee Debt Campaign), whilst others embedded it more selectively (Tearfund, Global Justice Now, CAFOD). Either way, it was used very strategically and at particular moments of campaign cycles. For instance, this could be seen across: Jubilee Debt Campaign's work on Essential Services and Debt Fuelling Conflict campaigns; CAFOD's Mining and Extractives campaign and business and human rights policy work, and; War on Want's Justice for Palestine and Profiting from Conflict campaigns. Participants repeatedly spoke of the need to be instrumental in how they communicated to different and wider audiences. For all, the utilisation of rights referencing could be accredited with potential power, influence, and/or authority, but critically only at key moments.

When looking at the complete data set - and in the context of explanation and argumentation - three overt uses of rights referencing rose to the fore. The first related to the use of rights talk before sympathetic audiences (such as key activists, supporters and likeminded people of influence). Essentially a discourse of rights was being used as a means to explain the underlying core message of the campaign. The following statement, made by Jubilee Debt Campaign's Director, is illustrative to this trend,

[One of the] areas where we do use rights, [is] in a lot of the argumentation for our work - whether in advocacy and policy, or general education - [which] is around the impact that public debt has on access to essential public services. So, although we rarely use the word "right to..." the argument that we make is that it is definitely a right! You know, "that everyone has a right to a good standard of affordable education, healthcare, housing, water, and that unjust public debt is undermining that, and that that is what we should be tackling." That is quite a central argument that we use.... human rights is helpful as a starting point, in establishing why the structures of debt are unjust, but it doesn't help any further when you need to talk about what needs to happen. ${ }^{58}$

On a similar note, but with a far greater emphasis on the attribute and significance of 'truth', War on Want's Executive Director explains, 
...human rights represent the truth that doesn't need to be unpicked. The solid article of faith that you start from.' [We would make reference to human rights] if we want to help people to understand things, in ways that are generally accepted. And it's quite nice to be able to ground our analysis in the stuff that is going to be acceptable to people. Without us having to say, right, here is something completely different. ... What we are trying to say is look, here is something that everyone agrees on, people's access to human rights, therefore here are the consequences. ${ }^{59}$

Both statements provide insight into the extent to which rights referencing is used as a basis to explain key parts of the main argument. In essence, rights talk is used as part of the initial process of reasoning (in support of the idea and actions campaigned for). The very identification of human rights as 'the solid article of faith' provides testament to its felt value.

The second use of rights referencing related to the loose appeal to rights discourses before new audiences. The following statement provides an interesting example of this trend,

... we very rarely appeal to rights to the expense of our core argument, we just add it on. So, it is kind of a gateway drug almost, to our deeper, more radical ideas. So, if we say, if you agree that this is a breach of rights, that this is bad, then, how about these [X, Y, and Z] reasons that are bad as well! It is kind of a gateway drug to a more radical argument. ${ }^{60}$

In many ways the labeling of rights talk as a 'gateway drug' neatly exemplifies what many of the research participants expressed in different ways. That is, whilst campaign teams were only too aware of the shortcomings of an approach firmly based on human rights, contemporary strategies involved the very deliberate invoking of rights referencing to engage new audiences. These strategies were used across a number of mediums (inclusive of print, digital and social media, as well as oral discussion and presentations).

The third use concerned communications with individuals and groups who held alternate ideological positions or worldviews (be them members of the public, activists or targets). The following statement offers a typical faith-based response,

My personal opinion is that rights are like a floor, so, it's the minimum that you want to get to. So, [faithbased teaching] goes further than that, and says "love all your neighbours as yourself" .... Caring about rights is just part of where the loving your neighbour takes you. So, it is compatible and it's a helpful concept to have, to try and go and influence people who aren't Christians, because partly the idea of it, and because the international and legal aspects too. But, it would be a tool that we would use to try and help persuade people, rather than a reason that we want to persuade them. ${ }^{61}$

This statement, like so many, reaffirms the reasons for rights referencing (by contrast to basing). Rights talk is essentially used as a ('compatible') 'tool' to advance certain lines of argument before key audiences. In quite a different, yet not too dissimilar way, the following account details how and when rights referencing is used by Global Justice Now before indifferent audiences, 
For us, it comes down to using it when it is useful, as a little thing in our pocket, that we can pull out as a trump card, and we can say to people, "oh but there is a right to free education"... And so [we would use rights] as a trump card to people who aren't anti-capitalist, who aren't even skeptical about capitalism, but do believe in rights. If we are honest, it is about broadening our audience. ${ }^{62}$

Despite the clear rejection of invoking human rights frameworks at the conceptual level (detailed earlier), there still remains a very strong and continued desire to firmly embed rights talk through different conduits of an NGOs' approach and campaign practice. This is clearly built on the sense of strategic value that rights talk is perceived to offer. It also provides insight into the different ways in which the research participants comprehend and interpret various rights claims (and, significantly, their associated value). Identifying these important uses of rights talk - through the process of referencing - serves to provide a further, and very critical, foundation for RRAs.

\section{De-mobilisation}

The strategic use of rights talk was not only observed in the act of argumentation and explanation, but in other practices too. Such practices provided further insight into how campaigners understand rights claims and the ways in which they accept and utilise a (more organic) discourse of rights at the operational level. For two of the (leftist) political NGOs (War on Want, Global Justice Now) a discourse of rights was used powerfully as a basis to respond to and de-mobilise antagonists.

For War on Want in particular this was considered to be an absolutely critical tool, especially supporting its Justice for Palestine campaign. This area of campaigning is one that has traditionally been an area of contestation for War on Want, partly due to a somewhat turbulent history before the Charity Commission for England and Wales. ${ }^{63}$ In June 2007 (during the first phase of the research project) War on Want formally changed its Charitable Objects to explicitly include both the 'relief of global poverty' and the 'promotion of human rights' as its key objective. ${ }^{64}$ This change did not denote a move towards RBAs, but rather it furthered its alternate use of a human rights discourse and practice. This embedding of rights talk came explicitly through the use of framing - and what in turn was a clear practice of a RFAs. War on Want was able to use this framing as a foundation on which a solidarity campaign with the political aspirations of the Palestinian peoples could be defended (precisely because key struggles could now be incorporated within a broader human rights discourse). Of late however, War on Want shifted its practice. That is, where it had previously framed various campaign messaging through a rights discourse, more recently (2014-2017) it made the deliberate choice to locate various positions through an explicit reference to ideas of universal 
rights. This subtle, yet important distinction enabled the repositioning of its overall approach to rights.

On reflection of War on Want's contemporary practice, the Chief Executive notes,

We use human rights a lot more in our more formal situations - whether its about our external communications in our framework, or whether it's us responding to the charity commission, we can still reference human rights more there. ... [T] he acceptability of human rights as a discourse is a useful bulwark against further restrictions that are on our work. It's almost as if we are trying to push the envelope, or push the agenda forward, but, we still need to have defense mechanisms to make sure we don't get pulled backwards. ${ }^{65}$

The Chief Executive's awareness of the strength of utilising human rights referencing is hugely significant. It is illustrative of the way in which practice has shifted for NGOs like War on Want, who clearly recognise both the limitations and concurrently the potency of invoking rights talk in precise situations and contexts. Likewise, participants from Global Justice Now also spoke of the importance of being able to 'pull out human rights' if they were challenged on their position (i.e. as and when needed).

What became unequivocal across these and various similar data was that despite different participants' caution about using human rights frameworks to base an approach, they were clear that the language of human rights still remained an important 'weapon' at the operational level. ${ }^{66}$ Such a notion was derived from a common understanding that the language of rights was still widely accepted. Indeed, for the vast majority of the participants involved in the project, there appeared to remain a legitimacy of rights talk within general western public discourses. This legitimacy in part stems from formal rights frameworks that are furthered through national laws (and thus have currency before institutions, like the Charity Commission for England and Wales), whilst also being simply 'widely accepted' within general public imaginations. Unsurprisingly therefore, the use of rights referencing before antagonists remains a powerful tool, and one that is central to RRAs.

\section{Expansion and transformation}

Data provided further examples of how an instrumental and strategic use of rights talk was being practiced. Four of the NGOs (Tearfund, Jubilee Debt Campaign, War on Want and Global Justice Now) pulled on the discourse of human rights as a means to expand and/or transform the terms and the nature of various debates (at local, national, regional and/or international levels). ${ }^{67}$ Specifically, rights talk was incorporated to enable broader campaign tactics, which strategically utilized key 
political moments to stand with others to call for a new right to be established (including rights to: water/ self-determination/ food/ learn/ free education/ find a home). These were used as a basis to challenge mainstream and internationalized debates and policy outcomes. They invoked rights talk by appealing to the idea of a universal right and used it as a tool to push the debate. Various participants noted the significant value of incorporating rights talk for this purpose.

[We] would talk about the expansion of the realms of rights. So, we would talk about, "why isn't there the established right to food, why isn't there a democratic control of a certain place?" ... We consider the realm of rights as set out by international institutions to be too narrow. And, you know, some organizations are about defending the rights that have already been recognized, whereas we are more about expanding the number of rights that people have. So, the "right to food" is a very good example of one that we would talk about. ${ }^{68}$

This statement also provides testament to the wider critique that groups like Global Justice Now maintain. Such an analysis is directed towards 'a lack of political will', 'soft power' and a broader liberal agenda that is perceived to be underpinning international legal rights regimes.

In contrast, participants from within the faith-based NGOs suggested a slightly different motivation. Their desire to expand and transform the debate was not so much about taking a political stand, as it was about finding a strategic way to articulate progressive aspects built within faith-based teachings. For example, CAFOD's Director of Advocacy and Communications ${ }^{69}$ explained how key ideas of rights (including, to: 'learn'; 'find a home'; live a 'life we deserve') formed part of a wider narrative that was seen to be more progressive than any legally based entity of rights. For this reason, such ideas were not grounded in an international law understanding but were based on a broader appeal to the idea of rights. They were used as a way to articulate aspects implicit in Catholic Social Teaching (and, especially Pope Francis' encyclical Laudato Si).

These findings stand in direct contrast to the practices of RBAs (as identified across the entire research project). The key difference is that RBAs were overwhelming observed to operate within established human rights frameworks (hence, the very notion of being rights-based). That is, being rights-based requires the NGO to directly start from a human rights framework (obviously in various ways) and, from that position, calls for the refinement of legal concepts and frameworks can be made. By contrast the examples that emerge from this data set identify that rights talk is being used to challenge existing frameworks from the position of being outside of any formal rights framework. The latter is a core aspect of RRAs.

\section{Multiple voices}


It was commonplace across all of the interviews (in all phases of the project) to speak of different internal voices, regarding: how, why and when a human rights discourse and practice had been incorporated in campaign practice. Participants often felt the need to reflect upon the fact that campaign (and, at times, programme) partners would use a human rights discourse and practice in quite different ways to UK and European-based campaigning contexts. For instance, participants from within CAFOD explained that whilst two thirds of CAFOD's partners were from Catholic churches, some contexts required a greater use of human rights discourses (for e.g. across Latin America), whilst other required less (for e.g. across Africa). Reasons for this difference respectively included wider societal uses of rights in key contexts, by contrast to the shutting down of civil society spaces in others. Likewise, participants from within Tearfund spoke of a more entrenched use of rights talk in contexts like Peru, whilst those within Jubilee Debt Campaign reflected on the broader Global Debt Movement (and, again, especially across Latin America), where rights discourses had become more centralised. Each participant also explained that if and/or when their respective campaigns aligned with partners who pulled heavily on a rights discourse, then - presuming there was an 'added value' - they too would embed a stronger discourse of rights. Consequently, a multiplicity of voices (dependent and time and location) is critical to RRAs.

\section{Significance and conclusions}

Since 2012 there has been a clear change in the campaigning contexts and environments within which development-orientated NGOs operate. This change - recorded during the second phase of the research project (2012-2017) - has impacted what many perceive to be the benefits and shortcomings of human rights practices. Changes in contexts and environments include: the mobilization of the Occupy Movement (which in turn lead to a greater drive for a more enhanced political analysis); the aftermath of the 2008 financial crash (which called for a deeper structural analysis of the global economy and global debt); the UK's 'Brexit' process (which led to instability, and calls to leave the wider European human rights system); developments in faith-based teachings (especially through the 2015 encyclical letter, Laudato $\mathrm{Si}$ ), alongside; more campaign specific moments (such as flashpoints in Palestine). As data from within this research project have illustrated, such environments and contexts have caused many to question the impact of embedding rights-based approaches. That is, many are seemingly more cautious about relying on approaches that require the embedding of human rights standards and principles as the primary unit for analysis and the principal framework for practice. Key reasons for this caution include the perception that RBAs are: based on a western bias; too liberal in their analysis; too legal or technocratic in their 
approach; too focused on the individual; too constraining and restrictive in their application, and for some; certainly not political enough. Indeed, by contrast to various findings in the existing literatures, ${ }^{70}$ many spoke of the de-politicised nature of RBAs.

What remains steadfast however is the apparent value of human rights. That is, it was clearly evident throughout the entire research project that the actual idea of universal human rights was not being called into question, nor was a practice of rights. Instead the strategic value of 'rights talk' prevailed (identified and used as a: 'solid article of faith'; 'trump card'; 'gateway drug'; 'compatible' value system; 'touchstone'; 'useful holding line'; 'bulwark'). In turn, a strategic use of rights referencing has become insurmountable to the success and longevity of leading development-orientated campaign strategies. Such findings do not therefore suggest an end in the merging of human rights and development, but more that all approaches do not represent coalescence. Or, as one research participant succinctly concluded, 'we are almost at the point where human rights are necessary, but not sufficient!'

The significance of these findings is demonstrated through the identification and proposal of rightsreferenced approaches. Such approaches build on the project's earlier contribution of rights-framed approaches. Critically, both approaches demonstrate how there are new and emerging human rights practices that operate outside of the broad umbrella concept of right-based approaches. Indeed, by contrast, these newer approaches operate as a tool, used to serve the overall policy of the NGO (rather than being used as the overarching approach). Rights-framed approaches are distinguished by the ways in which they incorporate the language of rights for the purpose of repacking the ideological underpinnings of an NGO in order to benefit from a number of strategic frame dimensions. On this basis, they utilise the power of the idea of universal rights to motivate others, but only when it is considered to be strategically advantageous to specific campaign contexts. By contrast, rights-referenced approaches invoke a more nuanced use of rights talk through the very deliberate embedding of rights referencing. They too are built on the identification that a human rights discourse or practice does not define the conceptual level of the NGO, but that rights talk and a rights practice is used instrumentally (and very precisely) at the operational level. Explicitly they appeal to the idea and discourse of rights: to enhance and strengthen the explanation and argumentation of core campaign messages and phases; to de-mobilise antagonists; to expand and transform the nature of different national/ regional/ international debates, and; (more rarely) to mobilise others to take action. Rights-referenced approaches accordingly exhibit a more purposeful 
and 'thinner' use of rights practice, by contrast to rights-framed and rights-based approaches (as illustrated in Figure 3 below).

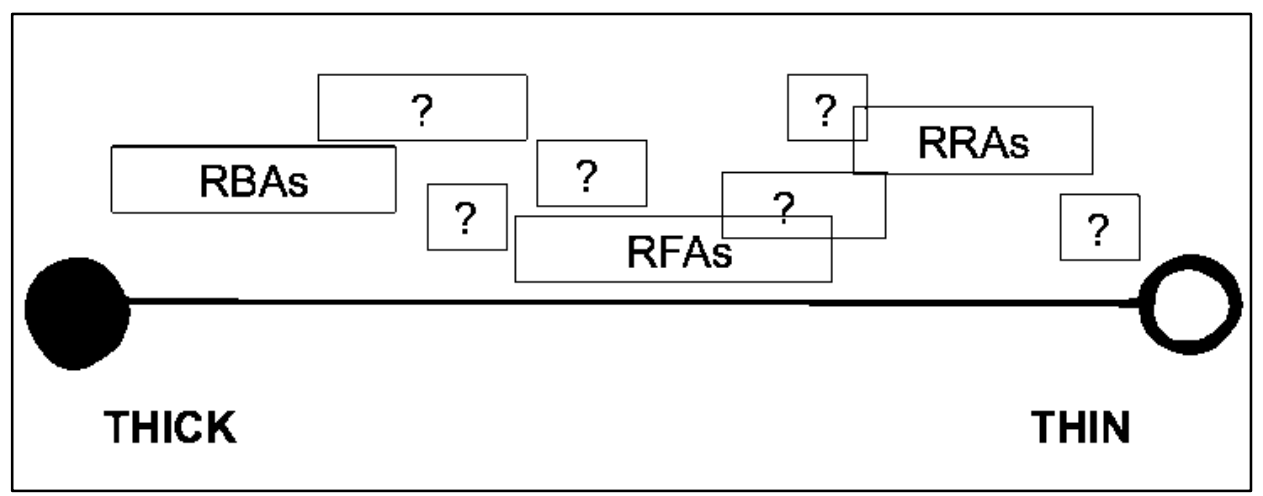

Figure 3. Locating rights-based approaches (RBAs), rights-framed approaches (RFAs), rightsreferenced approaches (RRAs) and other potential approaches across the human rights spectrum

There is a further level of importance to these findings. At the outset to this article the dominance of the broad umbrella concept of rights-based approaches within the existing literatures was identified and confronted (illustrated earlier, in Figure 1). Critically data analysed throughout this article have demonstrated that a rejection of rights-based approaches is not the same as a rejection of human rights discourses or practices. Instead, new in-depth and empirical data has demonstrated how leading practitioners are embedding new and innovative practices of rights in a variety of development contexts and with partners who operate across the globe. The identification and proposal of rights-referenced and rights-framed approaches offer new and important insights into this area of contemporary NGO practice. In so doing, they demonstrate that the inherent broad umbrella concept of rights-based approaches (as represented across the dominant literatures) should be seen as defunct, precisely because new approaches are continuing to emerge across the sector. Figure 3 illustrates the weight of these findings, with approaches plotted across the spectrum of human rights practice. Pictorially it also represents a wider call for new research that seeks to identify alternative approaches to rights-based ones (identified through the '?' boxes).

\section{Notes}

\footnotetext{
${ }^{1}$ Actors have included the UNDP, UNICEF, World Bank, the UK's departments for International Development and the Swedish International Development Cooperation Agency, Oxfam, Save the Children, ActionAid and CARE. See Andrea Cornwall and Celestine Nyamu-Musembi, 'Putting the "Rights-Based Approach" to Development into Perspective', Third World Quarterly 25, no. 8 (2004)
} 
${ }^{2}$ Maxine Molyneux and Sian Lazar, 'Doing the Rights Thing: Rights-Based Development and Latin American NGOs', Viewpoints (London: ITDG Publishing, 2003); Brigette Hamm, 'A Human Rights Approach to Development', Human Rights Quarterly 23(2001), 1005 - 1031; Celestine Nyamu-Musembi and Andrea Cornwall, 'What Is the "Rights-Based Approach" All About? Perspectives from International Development Agencies'. IDS Working Paper 234 (Brighton: IDS, 2004), 12-42; Emma Harris-Curtis, Oscar Marleyn and Oliver Bakewell, The Implications for Northern NGOs of Adopting Rights-Based Approaches (Oxford: INTRAC, 2005).

${ }^{3}$ Harris-Curtis, Marleyn and Bakewell, The Implications for Norther NGOs, 39-40; Joachim Theis, Promoting RightsBased Approaches: Experiences and Ideas from Asia and the Pacific (Stockholm and Bangkok: Save the Children Sweden, 2004), 19.

${ }^{4}$ Paul Nelson and Ellen Dorsey, New Rights Advocacy: Changing Strategies of Development and Human Rights NGOs (Washington, DC: Georgetown University Press, 2008), 93.

${ }^{5}$ Harris-Curtis, Marleyn and Bakewell, The Implications for Norther NGOs 39-40; Sam Hickey and Diana Mitlin, eds, Rights-Based Approaches to Development: Exploring the Potentials and Pitfalls (Sterling: Kumarian Press, 2009).

${ }^{6}$ Laure-Helene Piron, 'Rights-Based Approaches and Bilateral Aid Agencies: More Than a Metaphor?', IDS Bulletin: Developing Rights 36, no. 1 (2005), 19-30; Nelson and Dorsey, New Rights Advocacy.

${ }^{7}$ Hannah Miller, 'From 'Rights-Based' to 'Rights-Framed' Approaches: A Social Constructionist View of Human Rights Practice, International Journal of Human Rights, 14, no.6 (2010), 918; Hannah Miller and Robin Redhead, 'Beyond "Rights-Based Approaches"? Employing a process and outcomes framework', International Journal of Human Rights, (2019) this issue.

${ }^{8}$ Harris-Curtis, Marleyn and Bakewell, The Implications for Norther NGOs, 39-40.

${ }^{9}$ Wouter Vandenhole and Paul Gready, 'Failures and Successes of Human Rights-based Approaches to Development: Towards a Change Perspective', Nordic Journal of Human Rights 32, no.4 (2013), 291-311; Hamm, "A Human Rights Approach to Development." It should also be noted that there have been previous concerns related to whether development-orientated actors are discussing (and implementing) "rights-based" or "human rights-based" approaches, or whether they are one and the same thing. This issue appears to have arisen when actors have been inconsistent with the usage. As I have previously noted: 'broadly, some choose to emphasise the 'human', suggesting an alignment with the legal implications and normative quality of human rights as defined within international law. Others will use 'rights-based approaches' to indicate a certain distance from the international human rights system, with an increased association with citizen rights. Beyond this, the label 'rights-based approaches' can also represent a shorthand for 'human rights-based approaches"' Miller, 'From 'Rights-Based' to 'Rights-Framed' Approaches', 917. This article incorporates the latter.

${ }^{10}$ Shannon Kindornay, James Ron, and Charli Carpenter, 'Rights-Based Approaches to Development: Implications for NGOs', Human Rights Quarterly, 34, no. 2 (2012), 480.

${ }^{11} \mathrm{OHCHR}$, Frequently Asked Questions on a rights-based approach to development cooperation, (New York and Geneva, United Nations, 2006), 35 https://www.ohchr.org/Documents/Publications/FAQen.pdf

${ }^{11}$ OHCHR, Frequently Asked Questions. For a fully developed analysis of this see our introduction to this volume, Miller and Redhead, 'Beyond "Rights-Based Approaches"?

${ }^{12}$ Hamm, "A Human Rights Approach to Development"; Hickey and Mitlin's survey of RBA research has also led to the identification of RBA 'packages'. From this perspective, 'packages' (dependent on RBA 'interpretations') are likely to be inclusive of the following rights dimensions: '(Pressure for) formal rights as laid down within some legal systems, stipulations, rules, or regulations; The implementation of such rights through legal campaigns and stronger links with the legal profession; A more complete system of interconnected rights, rather than single rights; Adherence to international rights and a hierarchy of rights at local, national and international scales; The explicit acknowledgement that engaging with rights requires an overtly political approach' Hickey and Mitlin, Rights-Based Approaches, 8.

${ }^{13}$ Shela Patel and Diana Mitlin 'Reinterpreting the Rights-Based Approach: A Grassroots Perspective on Rights and Development', in Hickey and Mitlin, Rights-Based Approaches, 107-124; Vandenhole and Gready, 'Failures and Successes'; Hannah Miller, "Rejecting "Rights-Based Approaches" to Development: Alternative Engagements with Human Rights." Journal of Human Rights, 16, no.1 (2017).

${ }^{14}$ Paul Gready, 'Rights-based approaches to development: What is the added value? Development in Practice, 18, no. 6 (2008), 735-747; Paul Gready, 'Organisational Theories of Change in the Era of Organisational Cosmopolitanism: Lessons from ActionAid's human rights-based approach.' Third World Quarterly, 34, no. 8 (2013), 1339-1360; Kindornay, Ron, and Carpenter, 'Rights-Based approaches', 472-506; Hickey and Mitlin, Rights-Based Approaches to Development.

${ }^{15}$ For example, Vandenhole and Gready provide important insight into the 'drivers', 'obstacles' and 'spoilers' to organisational change. Vandenhole and Gready, 'Failures and Successes'

${ }^{16}$ See for instance, Gordon Crawford and Bard Andreassen, 'Human Rights and Development: Putting Power and Politics at the Centre.' Human Rights Quarterly, 37, no.3 (2015), 662-690.

${ }^{17}$ See Nelson and Dorsey, 'Who practices rights-based development? 97-107. 
${ }^{18}$ This is also core to the overall contribution of this special issue, see Miller and Redhead, 'Beyond "Rights-Based Approaches"?

${ }^{19}$ Kindornay, Ron, and Carpenter, 'Rights-Based approaches', 487.

${ }^{20}$ Peter Uvin, Human Rights and Development (Bloomfield, Kumarian Press, 2004).

${ }^{21}$ Laure-Hélène Piron, 'Rights-Based Approaches and Bilateral Aid Agencies: More Than a Metaphor? IDS Bulletin:

Developing Rights 36, no.1 (2005), 19-30.

${ }^{22}$ WB/OECD-Compendium, Integrating Human Rights into Development. Donor approaches, experiences, and challenges, Second Edition (Washington, World Bank, 2013).

${ }^{23}$ The categories suggested by Uvin and Piron and O'Neil straddle the spectrum of human rights practice, from thick to thin uses respectively.

${ }^{24}$ Niel Stammers, 'Social Movements and the Social Construction of Human Rights.' Human Rights Quarterly 21

(1999), 980-1008; Lydia Morris, Rights: Sociological Perspectives. London, Routledge (2006).

${ }^{25}$ Richard Ashby Wilson, 'Afterword to "Anthropology and Human Rights in a New Key": The Social Life of Human Rights.' American Anthropologist, 108, No.1 (2006), 77-83.

${ }^{26}$ Richard Ashby Wilson, 'Tyrannosaurus Lex: The Anthropology of Human Rights and Transnational Law.' The

Practice of Human Rights: Tracking Law Between the Global and the Local, Mark Goodale and Sally Engle Merry (Cambridge, Cambridge University Press, 2007),350.

${ }^{27}$ See Hannah Miller, 'From 'Rights-Based' to 'Rights-Framed' Approaches: A Social Constructionist View of Human Rights Practice' in Sociology and Human Rights: New Engagements, Pracillia Hynes, Michele Lamb, Damien Short, Matthew Waites (London, Taylor and Francis, 2012).

${ }^{28}$ Prior to 2015 'Global Justice Now' were formally known as the 'World Development Movement' (WDM). With the exception of one reference from 2005, they are referred throughout as 'Global Justice Now'.

${ }^{29}$ Of the respective list of nine, the first three had adopted RBAs, whilst the further six had not. The first three loosely represent mainstream RBA NGOs; the middle three, ('leftist') political NGOs, and; the final three, faith-based NGOs from either a Christian or Catholic tradition.

${ }^{30}$ Miller, "From 'Rights-Based' to 'Rights-Framed' Approaches, 923

${ }^{31}$ Miller, "From 'Rights-Based' to 'Rights-Framed' Approaches, 915-931; Miller,"Rejecting "Rights-Based Approaches" to Development.

${ }^{32}$ Global Justice Now, War on Want, Jubilee Debt Campaign, Tearfund and CAFOD

${ }^{33}$ In the wider research project the term 'conceptual level' was used in reference to: official approaches, conceptualizations of poverty, end goals and strategic priorities. The 'operational level' was in reference to the deployments of human rights discourses and practices within campaign activities. See Hannah Miller, From Rights-

Based to Rights-Framed Approaches: "Rights Talk", Campaigns and Development NGOs, PhD thesis (Roehampton, Roehampton University, 2010).

${ }^{34}$ The identification of these core areas emerges directly from the grounded approach of the research project, whilst also being inspired by the work of Snow and Benford, 'Ideology, Frame Resonance, and Participant Mobilization';

McAdam, McCarthy and Zald, 'Introduction'; Sidney Tarrow, Power in Movements: Social Movements and Contentious Politics, 2nd ed. (Cambridge: Cambridge University Press, 1998), Margaret Keck and Kathryn Sikkink, Activists Beyond Borders: Advocacy Networks in International Politics (Ithca, NY: Cornell University Press, 1998).

${ }^{35}$ Global Justice Now - focus group, 05 November 2015

${ }^{36}$ Global Justice Now - focus group, 05 November 2015; Jubilee Debt Campaign - Director, Interview, 22 February 2016

37 Tearfund - Senior Campaigner, Interview, 17 December 2015; CAFOD - Director of Advocacy and

Communications, Interview, May 2016.

${ }^{38}$ Jubilee Debt Campaign - Director, Interview, 22 February 2016; War on Want's Chief Executive, Interview, 28 August 2016

39 Jubilee Debt Campaign - Director, Interview, 22 February 2016; War on Want's Chief Executive, Interview, 28

August 2016; Global Justice Now - focus group, 05 November 2015

${ }^{40}$ For an interesting analysis, see Crawford and Andreassen, 'Human Rights and Development'. See also Andrea Cornwall and Celestine Nyamu-Musembi, "Why Rights, Why Now? Reflections on the Rise of Rights International

Development Discourse in 'Developing Rights'." IDS Bulletin, 36, no. 1 (2005); Uvin, Human Rights and Development.

${ }^{41}$ Global Justice Now - focus group, 05 November 2015; War on Want - Chief Executive, Interview, 13 October 2015;

Jubilee Debt Campaign - Director, Interview, 22 February 2016.

${ }^{42}$ Interview, 13 October 2015.

${ }^{43}$ This strategy is consistent with what Keck and Sikkink identify as 'solidarity campaign strategies', see Keck and

Sikkink, Activists Beyond Borders, 95.

${ }^{44}$ See Miller, "From 'Rights-Based' to 'Rights-Framed' Approaches. 
${ }^{45}$ Global Justice Now - focus group, 05 November 2015; Jubilee Debt Campaign - Director, Interview, 22 February 2016; Tearfund - Senior Campaigner, Interview, 17 December 2015; CAFOD - Director of Advocacy and Communications, Interview, May 2016.

${ }^{46}$ Interview, 05 October 2016

${ }^{47}$ War on Want - Chief Executive, Interview, 13 September 2016

${ }^{48}$ Global Justice Now - focus group, 05 November 2015; War on Want - Chief Executive, Interview, 13 September 2016.

${ }^{49}$ Jo Becker, Campaigning for Justice: human Rights Advocacy in Practice, (California, Standford University Press, 2013); Tess Kingram, The Good Campaigns Guide: Campaigning for Impact (NCVO, 2005)

${ }^{50}$ War on Want, Global Justice, Tearfund

${ }^{51}$ See Miller, "From 'Rights-Based' to 'Rights-Framed' Approaches; Miller,"Rejecting "Rights-Based Approaches" to Development.

52 Jubilee Debt Campaign - Director, Interview, 22 February 2016.

${ }^{53}$ Global Justice Now, Campaigns and Policy Officer, Interview, 05 November 2015.

${ }^{54}$ War on Want - Chief Executive, Interview, 13 October 2015, emphasis added.

55 Tearfund - Senior Campaigner, Interview, 17 December 2015; CAFOD - Director of Advocacy and Communications, Interview, May 2016.

${ }^{56}$ For instance, see Thomas Charman, 'Sexual violence of torture? The framing of sexual violence against men in armed conflict in Amnesty International and Human Rights Watch reports', in Marysia Zalewski, Paula Drumond, Elisabeth Prugl, Maria Stern. Eds. Sexual violence against men in global politics (London, Routledge, 2018); David Snow and Robert Benford, 'Ideology, Frame Resonance, and Participant Mobilization', in International Social Movement Research, 1

; McAdam, McCarthy and Zald, 'Introduction'; Sidney Tarrow, Power in Movements: Social Movements and Contentious Politics, 2nd ed. (Cambridge, Cambridge University Press, 1998), and Keck and Sikkink, Activists Beyond Borders.

${ }^{57}$ Miller, "From 'Rights-Based' to 'Rights-Framed' Approaches.

${ }^{58}$ Jubilee Debt Campaign - Director, Interview, 22 February 2016.

${ }^{59}$ War on Want - Chief Executive, Interview, 13 October 2015.

${ }^{60}$ Global Justice Now - Policy Officer, Interview, 05 November 2015.

${ }^{61}$ Faith-based NGO, interview (this statement has been anonymized following the 'in my personal opinion' prefix).

${ }^{62}$ Global Justice Now - Campaigns and Policy Officer, Interview, 05 November 2015.

${ }^{63}$ See Hannah Miller, 'A Change in Charity Law for England and Wales: Examining War on Want's Foremost Adoption of the new Human Rights Charitable Purpose.' International Journal of Human Rights, 16, no.7 (2012), 1003-1022.

${ }^{64}$ War on Want, Memorandum of Association of War on Want. London, War on Want (2007).

${ }^{65}$ War on Want - Chief Executive, Interview, 28 August 2016.

${ }^{66}$ For instance, the idea of a 'weapon' was discussed by War on Want's Chief Executive, Interview, 28 August 2016.

${ }^{67}$ Utilizing a frame as a means to transform the terms and nature of debate is of course a well-documented strategy of activists. See Keck and Sikkink, Activists Beyond Borders.

${ }^{68}$ Global Justice Now - Global Justice Now Policy Officer, group interview, 05 November 2015.

${ }^{69}$ Interview, 28 November 2016.

${ }^{70}$ See Cornwall \& Nyamu-Musembi, Putting the "Rights-Based Approach," supra note 5, at 1418, 1432; Crawford and Andreassen, 'Human Rights and development'. 